\title{
Correction: Treatment with native heterodimeric IL-15 increases cytotoxic lymphocytes and reduces SHIV RNA in lymph nodes
}

Dionysios C. Watson, Eirini Moysi, Antonio Valentin, Cristina Bergamaschi, Santhi Devasundaram, Sotirios P. Fortis, Jenifer Bear, Elena Chertova, Julian Bess, Jr., Ray Sowder, David J. Venzon, Claire Deleage, Jacob D. Estes, Jeffrey D. Lifson, Constantinos Petrovas, Barbara K. Felber, George N. Pavlakis

An affiliation is missing for the first author. In addition to the current affiliation information, Dionysios C. Watson is affiliated with: Department of Medicine, University of Patras, Greece.

\section{Reference}

1. Watson DC, Moysi E, Valentin A, Bergamaschi C, Devasundaram S, Fortis SP, et al. (2018) Treatment with native heterodimeric IL-15 increases cytotoxic lymphocytes and reduces SHIV RNA in lymph nodes. PLoS Pathog 14(2): e1006902. https://doi.org/10.1371/journal.ppat.1006902 PMID: 29474450

Citation: Watson DC, Moysi E, Valentin A, Bergamaschi C, Devasundaram S, Fortis SP, et al. (2018) Correction: Treatment with native heterodimeric IL-15 increases cytotoxic lymphocytes and reduces SHIV RNA in lymph nodes. PLoS Pathog 14(10): e1007345. https://doi. org/10.1371/journal.ppat.1007345

Published: October 11, 2018

Copyright: @ 2018 Watson et al. This is an open access article distributed under the terms of the Creative Commons Attribution License, which permits unrestricted use, distribution, and reproduction in any medium, provided the original author and source are credited. 